https://doi.org/10.18485/iipe_60nam.2021.ch23

\title{
AN EXIT FROM CONTRADICTIONS IN THE POST-COLD WAR DEVELOPMENT OF THE NON-ALIGNED MOVEMENT
}

\author{
Dragan BISENIĆ ${ }^{1}$
}

\begin{abstract}
Six decades after the First Conference of Non-Aligned Countries in Belgrade and three decades after the end of the Cold War, we have the opportunity to summarise the development of the Movement in its two basic phases: during the bipolar Cold War confrontation and the turbulent period after the collapse of the Eastern Bloc and the Soviet Union. The very fact that the Non-Aligned Movement managed to survive in two rather contradictory environments - the one for which it was formed and the other which is its formal negation - is impressive enough. Like other multilateral treaties and organisations, the Non-Aligned Movement faces uncertainties and seeks a new identity. The same is now happening with NATO, the European Union (EU), the Council of Europe and the CSCE (OSCE). With the exception of the United Nations, the Non-Aligned Movement is the broadest and most effective international political movement with as many as 120 member states.

Key words: the Cold War, George Kennan, Tito, modernisation of the NAM, Jakarta Summit, the crisis of the NAM, moral power, EU, pandemic, inequality, reshaping the Movement, 2030 Agenda.
\end{abstract}

\section{Introduction}

From the historical experience so far, it can be concluded that the end of the Cold War in Europe was partly due to the policy of the Non-Aligned Movement and the former Yugoslavia because both of these political actors sought to end the bloc division of the world through peaceful coexistence

\footnotetext{
${ }^{1}$ Ambassador of the Republic of Serbia to Egypt (2011-2018).

E-mail: dragan.bisenic@gmail.com
} 
and a fairer economic system and to stop the arms race and to eliminate the domination of large countries over small ones, without, of course, disputes arising in that process, which should, in any case, be resolved by peaceful means. The main principles of the non-aligned countries - independence, peaceful coexistence of countries with different systems, refusal and renunciation of the use of force in international relations, respect for the sovereignty and territorial integrity of countries, non-interference in the internal affairs of other countries and equitable world economic order, have remained the legacy and enduring values of this movement, which are now seeking ways to be also applied in the contemporary world. Today, 53 African, 26 South American and 36 Asian countries are members of the NonAligned Movement. Since 1998, Belarus has been the only European member of the Non-Aligned Movement. Malta and Cyprus were also its members until their accession to the EU. The organisation initially had two main goals: 1) non-alignment and 2) the national liberation or decolonisation of the Third World. The first two membership requirements were that 1) the country pursues an independent policy, based on the coexistence of states and non-alignment, or shows the tendency to pursue such policy and that 2) the country lastingly supports liberation movements.

Non-alignment can be discussed in terms of two related visions: as a foreign policy perspective for many new countries that gained political independence after the Second World War and as their broad international movement with the aim of achieving a substantial and structural change in international relations. While the first vision has already been achieved, the second still provides a strong basis for the survival and activities of the Movement. There are many who almost automatically argue that the NonAligned Movement was created at the Afro-Asian Conference in Bandung in 1955. In one of his critical analyses of non-alignment, Willetts contends that in this way the Movement is given "false roots" (Willetts, 1978). "(...) While I maintain non-aligned movement was not born until 1961 as a coherent group of ideas propounded by a group of relatively like-minded states, it has also been maintained by other people that non-alignment did not live beyond 1961". Dinkel arrived at the same conclusion following anticolonial, Afro-Asian and non-aligned conferences from Brussels in 1927, through Bandung in 1955 and Belgrade in 1961 to Jakarta in 1992 (Dinkel, 2018). Similar views can also be found in a comprehensive 12-volume collection of documents on non-alignment, which was published in 1978 (Jankowitsch, Odette, Sauvant, Weber, Jörg, 1978). Nevertheless, S.I. Keethaponcalan maintains that the "spirit of non-alignment" was created in Bandung: "Equally significant is the fact that Yugoslavia under Marshall Tito 
played a major role in moving the initial solidarity into the Non-Aligned Movement, with a relatively clear ideology and purpose" (Keethaponcalan, 2016). As the Soviet Union failed to prevent Tito from taking on a leading role in the Non-Aligned Movement during the turbulent 1960s, divisions within the communist world were deepened. Tito's actions and the formation of the Non-Aligned Movement as a global power already disrupted the Soviet monopoly over communist ideology, which had been dramatically weakened by Stalin's death in 1953 and the subsequent split between the Soviet Union and China (Niebuhr, 2011). The American Embassy in Belgrade analysed the First Conference of Non-Aligned Countries, which was held in Belgrade in 1961 and recorded that the presence of a large number of prominent persons had a very exciting impact on the population, which greeted the delegates whenever they appeared on the streets, and this happened up to four times a day. The participants were certainly flattered and pleased with such a welcome, which also had a favourable influence on their opinion of Yugoslavia. It was also concluded that a strong impression Yugoslavia left on all delegates was a reward for the efforts and financial costs invested in the organisation of this conference. It presented itself as a country with an efficient and vigorous government that meets the needs of its people and enjoys its support by setting exceptionally high political and economic development standards. Tito's criticism of the United States, although he promised he would not do that before the Conference, was experienced by the then American Ambassador in Belgrade and "father of the Cold War", George Kennan, with a deep disappointment and even the feeling of being betrayed (Bisenić, 2011). Since then, the controversial USNAM relations have alternated between acceptance and sharp differences (Rubinstein, A., 1978, p. 156). The turning point in the development of the Non-Aligned Movement took place at the end of the Cold War. When the 9th Summit was held in Belgrade in 1989, it became clear that the bipolar world was nearing its end and that the founding principles of the Movement's existence were slipping away. Perestroika in the Soviet Union was in full swing, so it was expected that the Belgrade Summit would modernise the paradigm of the Movement. Yugoslavia, which hosted this meeting, was convinced that the Movement needed a similar change of its policy at the global level if it wished to survive the challenges of the new times. Hence, Yugoslavia pleaded for the "modernisation of the Non-Aligned Movement", which actually implied the abandonment of the NAM's repulsive attitude towards the world's two power blocs (Syatauw, 1994). Instead, the NAM adopted a more tolerant and flexible position with an emphasis on cooperation and dialogue. The Yugoslav leaders were so 
strongly convinced of the need to change this policy that they accused those members of the NAM who disagreed with them of being dogmatic, conservative and radical. The earlier assumptions of ideological exclusivity and one-sided postulates were omitted in the final documents. The central focus was laid on a struggle to bridge the gap between the rich North and the poor South. The economic policies of the non-aligned countries were elaborated in detail in order to enable them to fit into the world division of labour as successfully as possible. Thus, the formula based on the East-West confrontation became obsolete. It must be noted that this formulation was also advocated and imposed by the then Yugoslavia. That was the "European" orientation of the Non-Aligned Movement. Many members of the NAM did not share the Yugoslav views, nor were they convinced that international political changes were of a lasting nature, no matter how profound they were. During the formulation of the final documents of the Belgrade Summit, Yugoslavia's views were only partly adopted, that is, only where the NAM explicitly approved the policy of dialogue and cooperation. In the Belgrade Declaration, it was also stated that, despite the improvement of the global political climate and easing of tensions, peace was not stable and there was no reason for excessive optimism. In a speech before the US Congress on 11 September 1990, US President George W. Bush described what he called a "new world order" as "a new era freer from the threat of terror, stronger in the pursuit of justice and more secure in the quest for peace, an era in which the nations of the world, East and West, North and South, can prosper and live in harmony (...)" (Bush, 1990). The non-aligned countries did not adopt the idea of a "new world order". Before the Ministerial Conference of the Non-Aligned Countries in Accra (Ghana) in September 1991, the world political situation had deteriorated further, including, among other things, the entire break-up of the Yugoslav federation. The report of the Accra Conference concluded that no consensus had been reached in support of the view that the Cold War had ended and that the New World Order had actually emerged (Accra Report, 1991). However, the meeting did reaffirm the earlier commitment to the policy of compromise and consultation (Accra Report, 1991, Para 1). This conference was attended by Živadin Jovanović, the then Yugoslav Ambassador in Luanda and later Minister of Foreign Affairs. He stated that he had received the instruction to discourage the formation of the Group of Friends of Yugoslavia within the Non-Aligned Movement because the solution of the Yugoslav problem had to be sought within the then European Economic Community (EEC). The other instruction was to invite Germany to attend the Ministerial Conference as a "guest" (Jovanović, 2020). It is paradoxical that immediately after the 
Belgrade Conference both Yugoslavia and its orientation vanished. Or, in other words, with the end of the Cold War one of its pillars also ceased to exist. This certainly had an impact on the character and nature of the Movement in the years that followed. The Jakarta Summit (as the 10th Conference of the Heads of State or Government of the Non-Aligned Countries is better known), which was held from 1 to 6 December 1992, began under rather difficult circumstances (Syatauw, 1994). The Jakarta Summit was attended by representatives of 100 countries and some 60 heads of state attended its sessions. Three years after the Belgrade Summit in September 1989, the post-Cold War world still failed to calm down. The disturbing effect of the collapse of the communist bloc in Eastern Europe and its drama teamed up with the turmoil in the Middle East when Iraq threatened Saudi Arabia and then attacked Kuwait. A large number of Arab non-aligned countries got involved in the conflict that the NAM alone could not resolve. The situation for the NAM worsened still further when the Balkan region was caught in the wave of political unrest in Yugoslavia, which held the chair of the NAM at that time. Some members argued that Yugoslavia had collapsed and no longer existed. Hence, it could no longer be a member of the NAM. However, there was also strong support for the opposite view that only some parts of the former Yugoslav federation had seceded and that the republics wishing to remain, Serbia and Montenegro, maintained the "state continuity and international and legal subjectivity of Yugoslavia" (Jovanović, 1993). Many African countries with a multi-ethnic population also favoured the latter view. There followed the debate on Yugoslavia's membership of the NAM in the broad outline and with the opposite views, which had been presented at the UN during a similar debate on Yugoslavia's membership of the UN (Blum, 1992). However, there was one fundamental difference. Unlike UN decisions, NAM decisions are taken by consensus, but due to so strongly divided parties, there was no consensus and, therefore, no decision could be achieved. Hence, the Yugoslav delegation was allowed to remain at the conference, pending the final decision on the legitimacy of its membership, which had to be taken at a special ministerial meeting of the NAM in New York in September 1992. Unfortunately, this meeting could not find the solution, so the resolution of this issue was postponed for an uncertain period of time. The then chairman, Indonesia, tried to resolve it, while the FR Yugoslavia agreed to suspend its participation in the NAM meetings and activities until its status in the international community is solved (Demian, 1993). 


\section{The Burial of a "Dead Horse":}

\section{A Discussion on the Survival of the Movement}

The discussion on Yugoslavia moved on, according to the same pattern, to another topic - the Movement itself. Since the end of the Cold War, two views on the vitality of the Movement in the contemporary world have been formulated:

1) According to the first view, the Non-Aligned Movement has survived the end of the Cold War, but has become superfluous because all countries now have different choices; moreover, there is a considerable number of those who argue that regardless of the number of the nonaligned countries, their influence is not felt in the world;

2) According to the other view, the values of the Non-Aligned Movement, especially its strong support for peace, the resolution of problems and conflicts by peaceful means, and the rejection of hegemony, still secure a place for it in the world today (Bisenić, 2020).

For now, it is enough to say that the Movement has survived and operates on the international scene. From 1989 to the present day, there were eight summits of the non-aligned countries. The fact that the Movement has survived as a form of action in the world shows that the majority of countries do not wish to repudiate the goals for which the Non-Aligned Movement has been fighting since its beginning. Giving an explanation of how and why the Movement managed to survive after the Cold War, Laura Hood states that non-alignment has got a new meaning vis-à-vis the attitude towards US politics and their Western allies (Hood, 2016). Over the past decades, some basic principles of non-alignment have been in collision with developments in international relations. This refers to non-interference in the internal affairs of other countries and respect for human rights. Analysing the changes in India's foreign policy in 2008, Carsten Rauch realised that India "distanced itself (too) far from the once cherished ideal of a non-aligned, moral foreign policy rooted in peaceful cooperation" under the increasing influence of the neoliberal economy and under pressure from the United States. She argues that the overriding important goal of India's foreign policy is to preserve its independence and ability to act, maximise Indian possibilities for influence and, put in quite general terms, make India into a global player "with a voice which will command attention in the shaping of the world order". According to Raja Mohan, to India, a country with almost no real power that could be demonstrated on the international stage, the Non-Aligned Movement offered the best path for the promotion 
of its diplomatic presence on the world stage (Mohan, 2004). "As long as India was very weak, non-alignment and involvement in the Non-Aligned Movement were perceived in New Delhi as a vehicle for drawing nearer to these goals. The stronger India becomes, the more any involvement in this movement loses its attraction" (Rauch, 2008). Since the very beginning, the Non-Aligned Movement has invoked its moral strength in international relations. Speaking in the Parliament in January 1953, Jawaharlal Nehru said that "... ultimately the foreign policy of every country is limited by the strength which that country possesses. Now, strength may be military or may also be, if I may use the word, moral. Obviously, India has no military or financial strength to go about interfering with other people, not that we want to. We have no desire to - and we cannot - impose our will on others." Consequently, there remained only moral strength as the basis for action in international relations. And moral strength was closely linked to the strict observance of international law from which the founding members of the Non-Aligned Movement derived their basic principles. Due to the increasing non-observance of international law, that is, the rights of other countries, the non-aligned position is becoming increasingly attractive to many countries in the world today. Alvin Rubinstein has written a compelling book on Tito and non-alignment, where he presented three primary strategic goals: to reinforce Yugoslav efforts to end the country's position of relative diplomatic isolation, to link Yugoslavia to the progressive forces in the world, and to develop markets in the Third World for Yugoslav enterprises. In the post-Cold War period, critics predominantly used negative terminology to describe this movement. In the West, the terms like "anachronous", "irrelevant", "disgraced" and "substantially superfluous" were usually used to describe the Non-Aligned Movement. One of the most important arguments was that this movement had no reason to exist and should be dissolved. So, before the 13th Summit, which was to be hosted by Bangladesh in 2002, and after the autumn 2001 election, the new government cancelled the hosting of this meeting at its first session. The new finance minister said that non-alignment was a "dead horse" and that Bangladesh should not spend its money on "horse burial" (Štrbac, 2020).

\section{The Gradual Irrelevance of the Goals}

The end of the Cold War was indeed a major blow to the Movement because most of the problems, such as apartheid and colonialism, gradually disappeared. Thus, the goals of the Movement changed from one summit to the next because its initial goals gradually became irrelevant. In contrast 
to Western political leaders, Third World leaders did not believe that it was necessary to dissolve the organisation only because its initial goals became irrelevant (Keethaponcalan, 2016). The new system, which was created after the Cold War, benefits strong and resource-rich countries, which cannot be said for any Third World country. Despite the problems faced by the NonAligned Movement, many countries wish to join it because they consider it a useful platform and support system. In the aftermath of the Cold War, one Western diplomat, who was observing the Jakarta Summit, expressed the opinion that "a lot of these tiny nations are praying that the (Non-Aligned) Movement can survive and advocate on their behalf" because "most of the nations are not capable of doing it for themselves". Nobody pays attention to them anymore (Shanon, 1992). The Non-Aligned Movement was not created for ideological reasons. It was not so much a response to a bipolar world, but a response to a non-free world, that is, a colonial system in which millions of people were in a subservient position, working and creating wealth for other countries. This prevented one's free presentation and expression of free will in international relations. The NAM imparted to its members a feeling of psychological security and removed the constant threat of isolation and psychological insecurity. The most economically powerful countries now use sanctions as a means to achieve their goals. In the past, it was Third World countries that imposed sanctions against other countries through the UN system, as in the case of aggression against sovereign countries or the apartheid system. The Non-Aligned Movement emerged from an intellectual quest for liberation from foreign domination and the liberation of cultural potentials in countries. Pankaj Mishra called it "intellectual decolonisation" (Mishra, 2017). The Movement is no longer a global actor as it used to be, but its policy that is not directed against the United States, the European Union, Russia or China makes the bloc popular among the members. Although the 120-member organisation represents the great majority of the UN members, the exclusion of the global powers, such as the United States, Russia, Western Europe and Japan, can limit the ability of these countries to have an influence on global trends or impose their decisions. During the Cold War, the Non-Aligned Movement was an instrument that enabled the developing countries to preserve their independence in the competition of the superpowers and their satellites. Although it was believed that the end of the Cold War marked the beginning of an era without wars and violence in international relations, the reality turned out to be different. Wars and increasingly strained relations among the world's leading countries, the United States, the European Union, Russia and China, as well as the new regional confrontations in North Africa, the 
Middle East, South East Asia and the Horn of Africa have revived the Cold War hotspots. The Balkans and the "post-Soviet space", including Central Asia, have not been bypassed. We must ask ourselves why life is getting harder and harder, why problems are accumulating and conflicts are multiplying, although the total wealth of the world is growing and so is the total human potential. The question also arises whether we should live in the era of "modern barbarism", where our human and state relations resemble barbaric ones, despite the most advanced achievements in the field of communications, industry and transport. Many studies and books have already been written describing the current and future periods as "global anarchy" (Kaplan, 1994) or "growing jungle" (Kagan, 2018). A long time ago, when the British Prime Minister, Lord Callaghan, asked Henry Kissinger what the 21st century would be like, the latter answered that it would be brutal and that he was very glad not to be living in it (Kissinger, 1999). One half of his prediction has already come true, and the other half has not. Henry Kissinger is still alive and can witness the reality of his prediction about the "brutal world". The Non-Aligned Movement is one form of a globalised world where all its problems also concern the nonaligned countries. Since its creation, especially in the Cold War era, the nonaligned countries were criticised for "embracing rigorous moral pretensions as a substitute for a rigorous analysis of the problem". Today, many countries, even the non-aligned ones, have rejected the ideas of morality and politics, value and politics and human rights and politics. They believe that they are able to pursue some particular national interests in the same way as the colonial powers did in the 19th century and that other countries cannot understand that as the basis of inequality and dominance and hegemonic intentions, and avoid that in a simple and easy way. Human rights and ethical political conduct, even in international relations, have just been included in interstate relations to protect the weak from the strong and guarantee equality to countries, small and big, rich and less rich. "Justice", "righteousness" and law are the most frequent values invoked historically by the Movement. It is faced with the option of multi-alignment instead of non-alignment as a temporary step that keeps all options open, just the way the great powers do it (Babu, 2012). And even if they belong to different groups, they still serve the same goal: to articulate their own views while at the same time preserving their strategic autonomy in global affairs. If we have to compare the political philosophy of today's world, we can go back and look for it in the "age of alliances", which followed the Congress of Vienna in 1815. Some believe that the alliance of conservative monarchies or powers secured peace and stability in Europe, so similar analogies are 
also made today. It is believed that an alliance of conservative countries and leaders could be an exit from uncertainty or that alliance and ally ships are the potential guarantee of stability. Some large countries have accused the Non-Aligned Movement of belonging to an "opportunistic bloc". However, the fact that the non-aligned countries have survived the end of the Cold War points to a significant political fact or a dilemma as to whether it is a question of inertia in international relations. Therefore, the question that imposes itself here is whether the Movement has remained efficient and relevant in the current international context. The current sharp confrontations and conflicts on the world stage have reopened the question of the betrayal of high human expectations after the end of the bloc division and the Cold War, and the necessity of explaining why this is so and why international relations have escalated into conflicts and tensions, which sometimes seem stronger than in the Cold War era. Today's criticism of the moral position starts from its weakness as an expression of the "liberal approach" to foreign policy. Criticising Nehru, Dr Rajesh Rajagopalan, Professor of International Politics at the Jawaharlal Nehru University Centre for International Politics, holds that, "from a Realist perspective, the key problem with a Nehruvian/liberal approach to foreign policy is that it misunderstands power and ignores the centrality of the balance of power politics in interstate relations" (Rajagopalan, 2012). Criticising India's document titled "Non-Alignment 2.0", Rajagopalan reproaches it for suggesting that India's influence is ideational and moral rather than material. "The problem is that while ideas matter, it is less important than material power and usually its servant. Morality, 'the power of example', is even more problematic because it is inconsequential in international politics. The seesawing Indian position in global affairs should be a good example: India's influence went from a high in the 1950s to the lows of the 1960s and resurgence over the past decade. This correlates nicely with power - India was courted and listened to in the 1950s, not because of India's moral power, but because it was seen as a potential great power," said Professor Rajagopalan. Responding to India's Foreign Minister Subrahmanyam Jaishankar that "non-alignment was a term of a particulate era and a particular ... geopolitical landscape", which could be understood as the notion about non-alignment being a relict of the Cold War-era world order and the recognition that the world has since moved towards a polycentric system with a handful of great powers competing to enhance their spheres of influence and establish their hegemony, A. Vinod Kumar concludes: "Non-alignment was not merely defined by the previous principles like neutrality and equidistance, but also by the autonomy of decision-making 
and flexibility of choices to act in the best interests of the country. As is evident from the many instances of realistic decision-making and unrelenting pursuit of national interests, non-alignment was a decisive practice of realist statecraft or pragmatic conduct of international relations. When seen from that perspective, the era of non-alignment could provide immense insights on how visionary leadership seeking to play an influential role in international politics could develop ideational frameworks that would propel the grand strategy of their choosing" (Kumar, 2020).

\section{The EU and "History Rhyming"}

The European Union (EU) was an observer at the Belgrade Summit in 1989. Amandeep Gill notes that "history rhymes" and that the European Union now seeks a NAM-like role, positioning it itself between the United States and China; "Today, as a new Cold War brews between China and the United States, Europe seeks a NAM-like role anchored in values, its own independent appreciation of where European interests lie, and is refusing to be drawn into either camp on issues such as trade, technology or freedom of navigation in the South Sea" (Gill, 2021). However, he does not believe that the EU's effort will end well. He goes on to say: "Europe's leading economic power, Germany, is a prime example, but so are EU members from Europe's periphery in the East and in the South. They want to profit from Chinese investments into European industry and infrastructure. They refuse to toe the US line on banning the Chinese telecom company Huawei from building $5 \mathrm{G}$ networks and see no harm in negotiating access to the Chinese market in exchange for investment concessions and a soft peddling of human rights concerts" (Gill, 2021). The pandemic drew attention to the importance of international cooperation and multilateral relations. Thus, on 4 May 2020, Josep Borrell, High Representative of the European Union for Foreign Affairs and Security Policy and Vice-President of the European Commission, participated in the Online Summit-level Meeting of the NonAligned Movement in response to COVID-19, titled "United against COVID-19" (Statement, 2020). The European official welcomed the NAM initiative and called on it to support a "coordinated multilateral approach" because the "coronavirus pandemic requires united global action in response". He emphasised that the international response should put people in the centre, fight against inequalities, and uphold human rights for all. He also pointed to the importance of fast and equitable access to safe, quality, effective and affordable diagnostics, therapeutics and vaccines against the 
coronavirus, where the EU participates in its "global response" with 20 billion Euros (Statement, 2020).

\section{The Changing World Order}

There are several reasons why the meetings of the non-aligned countries are still held: (a) there are still unresolved and new issues facing the Third World which require collective action; (b) the member countries can promote their national interests through the organisation that pulls together the countries of the "Global South", and (c) the international system is dynamic and constantly changing. The dynamics of the world order is constantly changing so that the old issues have taken a new form and the new issues that affect all members of the NAM have emerged. This "justifies" the need for the Movement to continue to exist because it may happen that the system with more "power centres" is shaped so that reshaping the Non-Aligned Movement will be an adequate response. It is expected that reshaping the Non-Aligned Movement will take three specific forms: (1) symbolic changes, (2) structural changes and (3) policy changes (S. I. Keethaponcalan, 2016). "Politically, the notion of non-alignment should be retained, not as the fundamental objective of the movement, but as one of the guiding principles. The movement should be able to work with major international actors, including power centres on selected issues, rather than becoming permanent allies or enemies of one or the other actor. This approach would have the potential to facilitate better outcomes from the movement's perspective" (Ketthapncalan, 2016). Changing the name of the organisation into the Solidarity Movement, for example, would be a symbolic change. Setting up some bodies of the NAM would be a structural change. The Movement has no permanent secretariat because its founders sought to ensure that it is not monopolised by a small group of countries, thus becoming only another bureaucratic form. "The importance of the NAM is becoming widely recognised, as more and more countries seek to become its members, while many developing countries are rapidly losing confidence in any type of alignment with big powers, especially military ones, which has often proved rather harmful. Therefore, non-alignment is still considered, albeit tacitly, to be an alternative to such a dominant system" (Čavoški, 2020). The general commitments that have determined the profile of the Movement since its formation remained unchanged in terms of the programme and goals: the struggle for peace, security, a guarantee of sovereignty, inviolability of the territory and integrity of states, and observance of international law. Today, we are witnessing exactly the 
opposite processes: international law is not observed, the territorial integrity of states is violated, and the argument of force is increasingly used in international relations, while diplomacy is suppressed and unable to show its effectiveness (Jevremović, 2020).

\section{The Goals of Sustainable Development and Multilateralism}

Customs wars, the withdrawal of large countries from international trade, and security and climate agreements pose a great challenge to all developing countries. The European Union is a market with 300 million people. The North Atlantic Free Trade Area (NAFTA) has 500 million people, and all this poses a huge task and problem for other countries to face them or compete with them. Therefore, collective economic development is of great importance for every country where the Movement can play an important role. Just like in the policy of pursuing the UN Sustainable Development Goals set in the 2030 Agenda. The Declaration adopted at the 18th Mid-Term Ministerial Meeting of the NAM, which was held in Baku on 5-6 April 2018, reaffirms the importance of multilateralism and emphasises the contribution of the non-aligned countries to the full implementation of the 2030 Agenda for Sustainable Development. The Meeting was focused on the topic "Promoting International Peace and Security for Sustainable Development". The member states called for further coordination in order to build a fair, inclusive, transparent and effective system of joint global governance and address the challenges and risks "stemming from global security threats, armed conflicts, environmental hazards, climate change, migration, contagious diseases, extreme poverty, among others". The Declaration singles out the following areas as being important for the NAM: South-South cooperation, multilateralism, the strengthening, modernisation and revitalisation of the United Nations "as the most democratic, accountable, universal and representative body", including the area of international peace and security, reform of the UN Security Council, fulfilment of all 17 Sustainable Development Goals, ending of poverty and hunger, as well as urging the developed countries to fulfil their commitments of providing finance, transfer of appropriate technology and capacity building to the developing countries, thus ensuring the fulfilment of the sustainable development goals. The Declaration emphasises climate change as a significant challenge and expresses concern about the impact of climate change, particularly on the developing countries, which is undermining their efforts to eradicate poverty and achieve sustainable development. Over the past 20 years, the 
Movement of the Non-Aligned Countries has sought to reconsider the veto power. The Movement has dealt with the need to reconsider the veto power in the Declarations of the Non-Aligned Summits held in Colombo (1976), Havana (1979), New Delhi (1983), Harare (1986), Belgrade (1989), Jakarta (1992) and Cartagena, Colombia (1995). The Cartagena Summit, held in October 1995, specified that the veto power was contrary to the goal of UN democratisation and, therefore, should be curtailed and subsequently eliminated. Several largest non-aligned countries such as Indonesia, Egypt, Argentina and Brazil are also G20 members, and they should be reckoned with in the ideas for the future UN reform. That is why the concept of nonalignment was so comprehensive and attempted to offer a new dimension of international relations, seeking different kinds of "new world order" from a new economic to a new information order in the world. It was the Non-Aligned Movement that affirmed the concept of "world order" that will emerge as a viable option of the universalisation of capitalism after the end of the Cold War and the disappearance of global communism, but with a completely different meaning and the ideas being different and far from those of non-alignment. The logic of the present but also of the future, that is, the logic of development contributes to the fact that among the members of the NAM, those from East Africa and South-East Asia, as well as India are especially successful in their development efforts. During the previous decades, until recently, the members of the Non-Aligned Movement were marginalised as the Third World countries, but many of them are now viewed as the countries that are growing economically and thus are imparted a new significance. The role of many member countries is increasing, either due to regional conflicts, such as the Middle East, or global integrative projects such as the Chinese "Belt and Road" Initiative. Russia, China and the West can understand that many positions of the members of the NAM must be taken into account, especially because global leaders seek regional partners in order to accomplish their goals, instead of taking unilateral actions. The non-aligned countries have a new opportunity to present themselves as a significant and constructive force in resolving international conflict issues as well as the issues of international and their own development. Bearing in mind that they constitute a significant majority of countries in the world, the non-aligned countries should take their share of responsibility for overcoming international confrontations, instability and the pandemic that poses a threat to all aspects of international relations - from security to tourism, but is also a mirror of the prevailing relations in the world divided into the rich and poor countries, into the developed and developing countries. 


\section{References}

Accra Report. (1991). Annex IT of the Report of the 10th Ministerial Conference of the NAM Accra, Jakarta, Media Centre of the 10th NonAligned Summit, 2-7 September.

Babu, Ramesh B. (2012). Nonalignment to Multialignment, World Affairs: The Journal of International Issues, 16(2), pp. 74-85.

Baku Declaration. (2018). The 18th Mid-Term Ministerial Meeting of the Non-Aligned Movement, Republic of Azerbaijan, 5-6 April.

Bisenić, Dragan. (2011). Mister X - Džordž Kenan u Beogradu (1961-1963), Beograd, Klub PLUS.

Blum, Y.Z. (1992). "UN Membership of the 'New' Yugoslavia: Continuity or Break?", AJIL, 86, pp. 830-833.

Blum, Y.Z. (1993). “Correspondents Agora: UN Membership of the Former Yugoslavia", AJIL, 87, pp. 240-251.

Bush, George H. W. (1990). Address Before a Joint Session of the Congress on the Persian Gulf Crisis and the Federal Budget Deficit.

Čavoški, Jovan. (2020). "Pokret nesvrstanih između istorijske važnosti i izgleda za budućnost", u: "Pokret nesvrstanih od Beograda 1989. do Bakua 2019 - 30 godina transformacije u vremenu neizvesnosti“" , Zbornik radova, Beograd, Klub PLUS.

Demian, Ana. (1993). "Echoes of Non-Alignment in the Balkans", RIA, 10161017, 1 May-1 June, p. 32.

Dinkel, Jürgen. (2018). The Non-Aligned Movement: Genesis, Organization and Politics (1927-1992), Brill.

Gill, Amendeep. (2021). Europe is the new NAM, Observer Research Foundation, retrieved from, https://www.orfonline.org/expertspeak/europe-is-the-new-nam/

Hood, Laura. (2021). Explainer: the Non-Aligned Movement in the 21st century, The Conversation, 28 September 2016, https://the conversation.com/explainer-the-non-aligned-movement-in-the-21stcentury-66057; accessed on 18 April 2021.

Jankowitsch, Odette, Sauvant Karl P., Weber Jörg. (1978). The Third World Without Superpowers I - XII, New York, Dobbs Ferry, Oceana Publications, Inc.

Jevremović, Pavle. (2020). "Razvojna pitanja zahtevaju novi pristup", u: "Pokret nesvrstanih od Beograda 1989. do Bakua 2019 - 30 godina 
transformacije u vremenu neizvesnosti“" Zbornik radova, Beograd, Klub PLUS.

Johnpoll, Alexander C. (1961). Memorandum of US Embassy, Belgrade, 14.11.1961, 396.1-BE, Central Decimal Files, Records of the Department of State, RG 59, collected by James G. Herschberg for GWCW/CWIHP. Jovanović, Vladislav. (1993). "Settlement of the Yugoslav Crisis by Peaceful Means", RIA 1012-13, 1 January-1 February, p. 1.

Jovanović, Živadin (2020). Pokret nesvrstanih i demokratizacija međunarodnih odnosa, u: "Pokret nesvrstanih od Beograda 1989. do Bakua 2019 - 30 godina transformacije u vremenu neizvesnosti“ , Zbornik radova, Beograd, Klub PLUS.

Kagan, Robert. (2018). The Jungle Grows Back, New York, Alfred A. Knopf.

Kaplan, D. Robert. (1994). "The Coming Anarchy", The Atlantic, February issue.

Keethaponcalan, S. I. (2016). "Reshaping the Non-Aligned Movement: challenges and vision", Bandung Journal of Global South.

Kissinger, Henry. (1999). Years of Renewal, New York, Simon \& Schuster.

Kumar, A. Vinod. (2020). In Defence of Non-alignment, The Manohar Parrikar Institute for Defence Studies and Analyses, retrieved from https:// idsa.in/issuebrief/in-defence-of-non-alignment-avkumar-020920

Mishra, Pankaj. (2017). Age of Anger - A History of the Present, New York, Ferrar, Straus and Giroux.

Mohan, Raja C. (2004). Crossing the Rubicon - The Shaping of India's New Foreign Policy, London, Palgrave Macmillan.

Niebuhr, Robert. (2011). “Nonalignment as Yugoslavia's Answer to Bloc Politics", Journal of Cold War Studies, 13(1), pp. 146-179, retrieved from: http:/ / direct.mit.edu/jcws/article-pdf/13/1/146/697719/jcws_a_ 00072.pdf, 24 April 2021.

Rajagopalan, Rajesh. (2012). Nonalignment 2.0: A Realist Critique of An Establishmentarian Perspective, The Manohar Parrikar Institute for Defence Studies and Analyses, retrieved from https://idsa.in/ idsacomments/Nonalignment2ARealistCritiqueofAnEstablishmentaria nPerspective_rrajagopalan_010512

Rauch, Carsten. (2008). “Farewell Non-Alignment? Constancy and change of foreign policy in post-colonial India", PRIF Reports, 85.

Shenon, Philip. (1992). "Non-Aligned Movement decides it is still relevant". The New York Times, retrieved from http://www.nytimes.com/1992/ 
09/07/world/non-aligned-movement-decides-it-is-still-relevant.html; accessed on 19 April 2021.

Statement. (2020). External Action Service, Online Summit of the NonAligned Movement: HR/VP Josep Borrell delivers a message calling for reinforced multilateralism in the fight of the corona virus, Brussels, 5 April.

Syatauw, J.J.G. (1994). “The Non-aligned Movement at the crossroads - The Jakarta Summit adapting to the Post Cold war era", Asian Yearbook of International Law, 3, pp. 129-162.

Willetts, Peter. (1978). The Non-Aligned Movement, the origins of a Third World alliance, London, Frances Pinter Ltd. 